\title{
Minimally invasive radioguided parathyroid surgery using low-dose Tc-99m-MIBI — comparison with standard high dose
}

\author{
Minimalnie inwazyjna paratyroidektomia pod kontrolą obrazowania \\ radioizotopowego - porównanie niskich i wysokich dawek Tc-99m-MIBI
}

\author{
Ali Jangjoo ${ }^{1}$, Ramin Sadeghi', Zohreh Mousavi ${ }^{3}$, Masoud Mohebbi ${ }^{3}$, Mahtab Khaje $^{4}$, Mehdi Asadi \\ ${ }^{1}$ Surgical Oncology Research Centre, School of Medicine, Mashhad University of Medical Sciences, Mashhad, Iran \\ ${ }^{2}$ Nuclear Medicine Research Centre, School of Medicine, Mashhad University of Medical Sciences, Mashhad, Iran \\ ${ }^{3}$ Endocrine Research Centre, School of Medicine, Mashhad University of Medical Sciences, Mashhad, Iran \\ ${ }^{4}$ Department of Surgery, School of Medicine, Mashhad University of Medical Sciences, Mashhad, Iran
}

\begin{abstract}
Introduction: Surgery remains the most effective treatment for primary hyperparathyroidism (PHPT). Minimally invasive radioguided parathyroidectomy (MIRP) is a common technique for detecting and excising abnormal parathyroid glands. The aim of this study was to compare injections of low-dose and high-dose $(99 \mathrm{~m})$ Tc methoxy isobutyl isonitrile (MIBI) for intraoperative localisation of parathyroid adenomas by means of a gamma probe in patients with primary hyperparathyroidism (PHPT).

Material and methods: Thirty patients with PHPT and a preoperative diagnosis of parathyroid adenoma were enrolled between 2010 and 2012. They were considered as Group B and underwent MIRP using $5 \mathrm{mCi}$ Tc-99m MIBI, and their perioperative data were compared with twenty patients treated with conventional $20 \mathrm{mCi}$ Tc-99m MIBI previously (Group A).

Results: Group A was made up of 20 patients (mean age, 41.55 years; 14 women and 6 men), and group B included 30 patients (mean age, 40.43 years; 19 women and 11 men). The mean serum parathyroid hormone (PTH) and calcium values were recorded pre- and postoperatively. The mean follow-up period for the patients in the two groups was 18.4 and 16.5 months, respectively. Pre-operative evaluation demonstrated that the groups were statistically similar. Intraoperative data and success rate of surgery showed no difference between the two groups. No significant complication was detected after surgeries and no recurrence happened in either of the two groups during the follow-up period.

Conclusions: A new protocol of MIRP using low doses of Tc-99m-MIBI resulted in an excellent success rate. Comparing results of the study, we conclude that low-dose Tc-99m-MIBI may be preferred for identification of parathyroid adenomas intraoperatively by means of a gamma probe in PHPT patients because it appears to be as effective as high-dose Tc-99m-MIBI. (Endokrynol Pol 2017; 68 (4): 398-401)

Key words: primary hyperparathyroidism; radioguided parathyroidectomy; radiation exposure
\end{abstract}

\begin{abstract}
Streszczenie
Wstęp: Najbardziej skutecznym leczeniem pierwotnej nadczynności przytarczyc (PHPT, primary hyperparathyroidism) nadal pozostaje zabieg chirurgiczny. Minimalnie inwazyjna paratyroidektomia z lokalizacją radioizotopową (MIRP, minimally invasive radioguided parathyroidectomy) jest techniką często stosowaną do wykrywania i wycinania nieprawidłowych przytarczyc. Badanie przeprowadzono w celu porównania małej i dużej dawki (99m) Tc metoksy-izobutylu-izonitrylu (MIBI) podawanych w celu śródoperacyjnej lokalizacji gruczolaków przytarczyc za pomocą sondy gamma u chorych z pierwotną nadczynnością przytarczyc (PHPT, primary hyperparathyroidism).

Materiał i metody: W latach 2010-2012 do badania włączono 30 chorych z PHPT i przedoperacyjnym rozpoznaniem gruczolaka przytarczyc. W tej grupie chorych określonej jako grupa B wykonano MIRP po podaniu $5 \mathrm{mCi}$ Tc-99m MIBI, a dane okołooperacyjne tych chorych porównano z danymi 20 pacjentów, u których zastosowano konwencjonalną dawkę 20 mCi Tc-99m MIBI (grupa A).

Wyniki: Grupa A składała się z 20 chorych (średnia wieku 41,55 r.; 14 kobiet i 6 mężczyzn), a grupę B tworzyło 30 chorych (średnia wieku 40,43 r.; 19 kobiet i 11 mężczyzn). Zmierzono przed-i pooperacyjne stężenia w surowicy parathormonu (PTH, pathyroid hormone) i wapnia. Średni okres obserwacji chorych w grupach A i B wynosił odpowiednio 18,4 i 16,5 miesiąca. Ocena przedoperacyjna wykazała, że grupy nie różniły się statystycznie między sobą. Również dane śródoperacyjne odsetek zabiegów zakończonych powodzeniem były podobne w obu grupach. W żadnej z grup nie stwierdzono istotnych powikłań pozabiegowych ani nawrotu w okresie obserwacji.

Wnioski: Nowy protokół MIRP z użyciem małych dawek Tc-99m-MIBI wiązał się z bardzo wysokim odsetkiem pomyślnych zabiegów. Porównanie wyników uzyskanych w badaniu pozwala sformułować wniosek, że do śródoperacyjnego identyfikowania za pomocą sondy gamma gruczolaków nadnercza u chorych z PHPT mogą być preferowane małe dawki Tc-99m-MIBI, ponieważ są równie skuteczne jak duże dawki Tc-99m-MIBI. (Endokrynol Pol 2017; 68 (4): 398-401)
\end{abstract}

Słowa kluczowe: pierwotna nadczynność przytarczyc; paratyroidektomia pod kontrolą obrazowania radioizotopowego; ekspozycja na promieniowanie

Mehdi Asadi, Surgical Oncology Research Centre, School of Medicine, Mashhad University of Medical Sciences, Mashhad, Iran, phone/fax : +98-51-38525255, e-mail: asadi_mdr@yahoo.com, asadimh@mums.ac.ir 


\section{Introduction}

Hyperparathyroidism is an endocrine disorder characterised by excessive secretion of parathyroid hormone $(\mathrm{PTH})$, which can cause various symptoms and severe morbidities. Primary hyperparathyroidism (PHPT) is due to excessive secretion of parathyroid hormone by one or more parathyroid glands [1].

PHPT is a common clinical endocrine disorder in many countries. The prevalence of PHPT has recently increased compared to the past, maybe as a result of improved biochemical tests [2]. Almost 1 out of every 2000 men and 1 out of every 500 women are affected by this disease each year. In more than $80 \%$ of PHPT patients, a single parathyroid adenoma is detected. The second common cause of PHPT is parathyroid hyperplasia (15-20\% of all patients). Multiple parathyroid adenomas and parathyroid carcinomas are other less common causes [3].

The only curative treatment for hyperparathyroidism is surgery. The first successful parathyroidectomy was performed in 1925, with bilateral neck exploration, and since then this has remained the standard treatment of PHPT $[4,5]$. Although bilateral neck exploration is still the traditional surgical approach, selective parathyroidectomy can also be performed using minimally invasive, video-assisted, endoscopic, or radio-guided techniques [6-7]. With the introduction of Tc-99m-sestamibi scintigraphy to identify and locate the parathyroid adenoma preoperatively, the era of minimally invasive radioguided parathyroidectomy (MIRP) began [8]. MIRP is gradually being replaced traditional bilateral neck exploration as the procedure of choice in many institutions, with comparable results [9]. MIRP is a less invasive surgical approach to hyperparathyroidism, which could decrease the time, hospital stay, and cost of parathyroid surgery [10-12].

The usual technique for MIRP is intravenous injection of 20-25 mCi Tc-99m-MIBI 2-4 hours before the operation and use of an intraoperative gamma probe for localisation of the abnormal parathyroid glands. This protocol offers the advantage of performing parathyroid scintigraphy and surgery on the same day [13-15]. Later, Murphy and Norman proposed the so-called "20\% rule" that has been reported to yield $100 \%$ accuracy in distinguishing solitary parathyroid adenomas from hyperplasia during MIRP [16].

One of the main concerns of any radioguided surgery is the radiation exposure to the patient and the surgical staff. The patient's exposure is limited to one operation. But the surgeon and the operating room staff are repeatedly exposed to radiation during multiple procedures [17]. Usually there are a large number of different sources of radiation in these areas; however, during MIRP there is a unique source of radiation: the patient [18]. A large number of studies have been conducted to reduce the dose of radiotracers during surgeries [19-23].

In the current study, we used low-dose $(5 \mathrm{mCi})$ Tc-99m-MIBI for MIRP with a separate day protocol and compared the results with standard high dose (20 mCi) regarding demographics, clinical presentations, and surgical outcomes.

\section{Material and methods}

All patients with primary hyperthyroidism were included in the study with informed consent if meeting the following criteria: a) evidence of solitary parathyroid adenoma on the pre-operative Tc-99m-MIBI scintigraphy, b) no thyroid nodule on palpation or preoperative ultrasound evaluation, c) no history of multiple endocrine neoplasia (MEN) or familial hyperparathyroidism, d) no history of previous neck surgery or radiation, and e) follow-up for at least six months.

From March 2007 to December 2009 (Group A), the patients received $20 \mathrm{mCi}$ Tc-99m-MIBI intravenously three hours before surgery. All patients underwent general anaesthesia for surgical removal of abnormal parathyroid glands. A hand-held gamma probe (Europrobe, GMS, France) was used for mapping the radioactivity and localisation of the abnormal gland. After spotting the hottest point in the neck (which was correlated with the pre-operative Tc-99m-MIBI scintigraphy), a small $(2-3 \mathrm{~cm})$ incision was made over the point, and under the guide of the probe the hot parathyroid tissues were removed. The ex vivo radioactivity from the excised tissue was recorded and the equivalent radioactivity from the background surgical field was measured (in counts per second of gamma radiation). The procedure was considered successful if radioactivity in the excised tissue was at least $20 \%$ of the background activity and it was morphologically consistent with the parathyroid gland. No drains were used. The operation time was recorded from incision to complete closure in all patients. The serum calcium and serum PTH were measured the next day after surgery and before discharge.

Intra-operative PTH assay was not used. Special care was taken to preserve the recurrent laryngeal nerve.

From January 2010 to October 2012 (Group B), we changed the dose of Tc-99m-MIBI to $5 \mathrm{mCi}$. The remaining aspects of surgical treatment protocol remained the same.

We compared the success of surgery (based on pathology results, decrease in PTH and serum calcium levels post-operatively), rate of complications, ex vivo count rates of the abnormal glands, and background and surgical parameters between group A and B patients. 
Table I. Perioperative characteristics of the patients

Tabela I. Charakterystyka okresu okołooperacyjnego pacjentów

\begin{tabular}{|c|c|c|c|}
\hline & $\begin{array}{l}\text { Group A } \\
N=20\end{array}$ & $\begin{array}{l}\text { Group B } \\
\mathbf{N}=\mathbf{3 0}\end{array}$ & p-value \\
\hline Age (year) & $41.55 \pm 10.25$ & $40.43 \pm 12.34$ & 0.85 \\
\hline Gender (Female:Male) & $14: 6$ & 19:11 & 0.48 \\
\hline Size of Adenoma [mm] & $\begin{array}{l}22.25 \pm 6.5 \\
\text { (range, 11-36) }\end{array}$ & $\begin{array}{l}25.84 \pm 5.12 \\
\text { (range, 10-45) }\end{array}$ & 0.59 \\
\hline $\begin{array}{l}\text { Mean Operation time } \\
\text { [min] }\end{array}$ & $\begin{array}{l}36.65 \pm 7.5 \\
\text { (range, 20-54) }\end{array}$ & $\begin{array}{l}35.46 \pm 8.5 \\
\text { (range, 18-75) }\end{array}$ & 0.84 \\
\hline $\begin{array}{l}\text { Mean Length of } \\
\text { incision }[\mathrm{mm}]\end{array}$ & $\begin{array}{l}32.45 \pm 1.5 \\
\text { (range, 30-40) }\end{array}$ & $\begin{array}{l}34 \pm 2.4 \\
\text { (range, 30-45) }\end{array}$ & 0.54 \\
\hline $\begin{array}{l}\text { Conversion to } \\
\text { conventional neck } \\
\text { exploration }\end{array}$ & 1 & 0 & \\
\hline RLN injury & 0 & 0 & \\
\hline $\begin{array}{l}\text { Permanent } \\
\text { hypoparathyroidism }\end{array}$ & 0 & 0 & \\
\hline Transient hypocalcemia & 3 & 5 & 0.85 \\
\hline $\begin{array}{l}\text { Mean follow up } \\
\text { (months) }\end{array}$ & $\begin{array}{l}18.4 \pm 5.2 \\
(11-40)\end{array}$ & $\begin{array}{l}16.5 \pm 4.8 \\
(10-36)\end{array}$ & 0.74 \\
\hline
\end{tabular}

All data were analysed using SPSS 16, and the results were expressed as mean $\pm 1 \mathrm{SD}$. Comparison of the data was performed by Mann Whitney-U and Chi-square tests. Results with p values lower than 0.05 were considered significant.

\section{Results}

Overall, 50 patients included in the study. Twenty patients received the standard high dose $(20 \mathrm{mCi})$ of Tc-99m-MIBI. In this group (group A), the $20 \%$ rule could be achieved in 19 patients, and only one patient underwent bilateral neck dissection. Thirty patients received low-dose $(5 \mathrm{mCi}) \mathrm{Tc}-99 \mathrm{~m}-\mathrm{MIBI}$. In this group (group B), the $20 \%$ rule was achieved in all patients, and no bilateral neck dissection was performed.

The mean age was 41.55 years (range, 26-68 years) and 40.43 years (range, 24-61 years) in groups A and group B, respectively. No significant difference was detected in the female: male ratio between the two groups. Traditional bilateral neck exploration via a transverse neck incision was performed in only one case in group $\mathrm{A}$ and in none of the cases in group B (Table I).

The mean operative time was 36.65 minutes (range, 20-54 minutes) in group A and 35.46 minutes (range, 18-75 minutes) in group $B$, which was calculated after excluding the only case with conversion to bilateral neck exploration for group A. The length of the incision in two groups was measured with no statistically
Table II. Intraoperative radioactivity findings

Tabela II. Śródoperacyjne wyniki dotyczące promieniowania

\begin{tabular}{llll}
\hline & $\begin{array}{l}\text { Group A } \\
\mathbf{N}=\mathbf{2 0}\end{array}$ & $\begin{array}{l}\text { Group B } \\
\mathbf{N}=\mathbf{3 0}\end{array}$ & p-value \\
\hline $\begin{array}{l}\text { Ex vivo parathyroid } \\
\text { adenoma counts } \\
\text { (counts/seconds) }\end{array}$ & $436 \pm 212$ & $396 \pm 184$ & 0.46 \\
\hline $\begin{array}{l}\text { Background tissue } \\
\text { counts } \\
\text { (counts/seconds) }\end{array}$ & $240 \pm 94$ & $238 \pm 84$ & 0.40 \\
\hline $\begin{array}{l}\text { Ratio of adenoma to } \\
\text { background counts (\%) }\end{array}$ & $178.4 \pm 52$ & $1.65 \pm 36$ & 0.55 \\
\hline
\end{tabular}

significant deference. The size of the removed parathyroid adenomas was similar in Group A and Group B (22.25 $\pm 6.5 \mathrm{~mm}$ vs. $25.84 \pm 5.12 \mathrm{~mm}$, respectively) (Table I).

Using a hand-held gamma probe, counts per seconds were obtained from ex vivo excised gland and the background field where the gland was removed (Table II).

Serum calcium and serum PTHwere measured before and after operation. The results are shown in Table III. In all patients in the two groups there was more than a 50\% decrease in PTH levels in the first postoperative day with respect to preoperative serum PTH levels. The postoperative first day calcium levels in all patients, in both groups, reduced to normal range.

There were no recurrent laryngeal nerve injuries and no wound complications such as infection or hematoma in two groups. No patient was affected by permanent hypoparathyroidism, although a few cases of transient hypocalcaemia were observed in both groups with no statistically significant difference ( $p$ value $=0.85$ ). All of them were treated accordingly with excellent outcomes.

MIRP was successful in all patients of both groups based on pathology and laboratory results including serum PTH and serum calcium, postoperatively.

No recurrences happened and all patients remained free of hypercalcaemia during a follow-up of 18.4 months (range, 11-40 months) in group A and 16.5 months (range, 10-36 months) in group $B$.

\section{Discussion}

Most patients presenting with PHPT have a single adenoma, and surgical excision has remained the standard of care, with a very low rate of complications and excellent results [4, 24]. Patients enjoy a very good quality of life postoperatively, and a quick return to age- and sex-matched life span is expected in almost all of them. 
Table III. Preoperative and postoperative serum PTH and calcium Tabela III. Przedoperacyjne i pooperacyjne stężenie PTH i wapnia

\begin{tabular}{|c|c|c|c|c|c|c|}
\hline & $\begin{array}{l}\text { Group A } \\
\mathbf{N}=\mathbf{2 0}\end{array}$ & & & $\begin{array}{l}\text { Group B } \\
\mathbf{N}=\mathbf{3 0}\end{array}$ & & \\
\hline & Preoperative & Postoperative & & Preoperative & Postoperative & \\
\hline $\begin{array}{l}\text { Total serum } \\
\text { calcium }[\mathrm{mg} / \mathrm{dl}]\end{array}$ & $11.6 \pm 0.6$ & $9.8 \pm 0.8$ & 0.02 & $11.4 \pm 0.5$ & $9.2 \pm 0.6$ & 0.01 \\
\hline $\begin{array}{l}\text { Serum parathyroid } \\
\text { hormone }[\mathrm{pg} / \mathrm{ml}]\end{array}$ & $945 \pm 364$ & $61 \pm 36$ & 0.001 & $894 \pm 312$ & $48 \pm 28$ & 0.001 \\
\hline
\end{tabular}

There are different protocols for a surgical approach to PHPT. Norman's protocol consists of three main steps. First, the patient is injected with $20 \mathrm{mCi}$ of Tc-99-MIBI in a nuclear medicine facility. Second, a dual phase scintigraphy technique is used to perform preoperative imaging. Finally, the patient is operated using a gamma-probe in about three hours. Our protocol presents some differences, including preoperative and surgery in separate days and injection of a four-times lower dose of Tc-99m-MIBI. Despite these differences, the results were comparable and promising. Besides, the so-called " $20 \%$ rule" was achieved in all patients who had received a lower dose Tc-99-MIBI.

Based on the data of the present study, it can be concluded that a Tc-99 MIBI dose as low as $5 \mathrm{mCi}$ appears to be adequate to perform MIRP with similar results in comparison to the conventional dose of $20 \mathrm{mCi}$. There is also a valuable advantage of decreased radiation exposure to the surgical staff and patient due to this lowered dose of Tc-99 MIBI.

\section{References}

1. Bilezikian JP, Silverberg SJ. Clinical spectrum of primary hyperparathyroidism. Rev Endocr Metab Disord. 2000; 1(4): 237-245, indexed in Pubmed: 11706737.

2. Kim HGu, Kim WY, Woo SUk, et al. Minimally invasive parathyroidectomy with or without intraoperative parathyroid hormone for primary hyperparathyroidism. Ann Surg Treat Res. 2015; 89(3): 111-116, doi: 10.4174/astr.2015.89.3.111, indexed in Pubmed: 26366379.

3. Soyder A, Ünübol M, Ömürlü İK, et al. Minimally invasive parathyroidectomy without using intraoperative parathyroid hormone monitoring or gamma probe. Ulus Cerrahi Derg. 2015; 31(1): 9-14, doi: 10.5152 UCD.2014.2572, indexed in Pubmed: 25931949.

4. Kaplan EL, Yashiro T, Salti G. Primary hyperparathyroidism in the 1990s. Choice of surgical procedures for this disease. Ann Surg. 1992; 215(4) 300-317, indexed in Pubmed: 1558410.

5. Rose DM, Wood TF, Van Herle AJ, et al. Long-term management and outcome of parathyroidectomy for sporadic primary multiple-gland disease. Arch Surg. 2001; 136(6): 621-626, doi: 10.1001/archsurg.136.6.621, indexed in Pubmed: 11386997.

6. Quillo AR, Bumpous JM, Goldstein RE, et al. Minimally invasive parathyroid surgery, the Norman $20 \%$ rule: is it valid? Am Surg. 2011; 77(4): 484-487, indexed in Pubmed: 21679561.

7. Stack BC, Moore ER, Belcher RH, et al. Hormone, relationships of parathyroid gamma counts, and adenoma mass in minimally invasive parathyroidectomy. Otolaryngol Head Neck Surg. 2012; 147(6): 1035-1040 doi: 10.1177/0194599812458767, indexed in Pubmed: 22922760.

8. Rubello D, Pelizzo MR, Casara D. Nuclear medicine and minimally invasive surgery of parathyroid adenomas: a fair marriage. Eur J Nucl Med Mol Imaging. 2003; 30(2): 189-182, doi: 10.1007/s00259-002-0983-2, indexed in Pubmed: $\underline{12643287}$.
9. Sackett WR, Barraclough B, Reeve TS, et al. Worldwide trends in the surgical treatment of primary hyperparathyroidism in the era of minimally invasive parathyroidectomy. Arch Surg. 2002; 137(9): 1055-1059, doi: 10.1001/archsurg.137.9.1055, indexed in Pubmed: 12215160.

10. García-Talavera P, García-Talavera JR, González C, et al. Efficacy of invivo counting in parathyroid radioguided surgery and usefulness of its association with scintigraphy and intraoperative PTHi. Nucl Med Commun. 2011; 32(9): 847-852, doi: 10.1097/MNM.0b013e328349576f, indexed in Pubmed: 21760559.

11. Fujii T, Yamaguchi S, Yajima R, et al. Use of a handheld, semiconductor (cadmium zinc telluride)-based gamma camera in navigation surgery for primary hyperparathyroidism. Am Surg. 2011; 77(6): 690-693, indexed in Pubmed: 21679634.

12. Tardin L, Prats E, Andrés A, et al. [Ectopic parathyroid adenoma: Scintigraphic detection and radioguided surgery]. Rev Esp Med Nucl. 2011; 30(1): 19-23, doi: 10.1016/j.remn.2010.09.003, indexed in Pubmed: 21208692.

13. Jangjoo A, Forghani MN, Memar B, et al. Minimally Invasive Radioguided Surgery for Hyperparathyroidism: An Experience with Tc-99m Sestamibi. Iran J Nucl Med. 2009; 17(1): 12-7.

14. Caudle AS, Brier SE, Calvo BF, et al. Experienced radio-guided surgery teams can successfully perform minimally invasive radio-guided parathyroidectomy without intraoperative parathyroid hormone assays. Am Surg. 2006; 72(9): 785-9; discussion 790, indexed in Pubmed: 16986387.

15. Ikeda $Y$ Takayama J Takami $\mathrm{H}$. Minimally invasive radioguided parathyroidectomy for hyperparathyroidism. Ann Nucl Med. 2010; 24(4): 233-240, doi: 10.1007/s12149-010-0366-x, indexed in Pubmed: 20333484.

16. Murphy $\mathrm{C}$, Norman J. The $20 \%$ rule: A simple, instantaneous radioactivity measurement defines cure and allows elimination of frozen sections and hormone assays during parathyroidectomy. Surgery. 1999; 126(6): 1023-1029, doi: $10.1067 / \mathrm{msy} .2099 .101578$, indexed in Pubmed: 10598183.

17. Bekis R, Celik P, Uysal B, et al. Exposure of surgical staff in surgical probe applications in radioguided parathyroidectomy. Eur Arch Otorhinolaryngol. 2008; 265(12): 1545-1548, doi: 10.1007/s00405-008-0716-7, indexed in Pubmed: 18542982.

18. Kristoffersen US, Straalman K, Schmidt G, et al. Radiation exposure to surgical staff during hyperthermic isolated limb perfusion with $99 \mathrm{~m}$ Technetium labeled red blood cells. Int J Hyperthermia. 2009 Feb. 25(1): 86-9.

19. Rubello D, Mariani G, Pelizzo MR. Minimally invasive radio-guided parathyroidectomy on a group of 452 primary hyperparathyroid patients: refinement of preoperative imaging and intraoperative procedure. Nuklearmedizin. 2007; 46(3): 85-92, doi: 10.1160/nukmed-0036, indexed in Pubmed: 17549319

20. Rubello D, Mariani G, Al-Nahhas A, et al. Minimally invasive radio-guided parathyroidectomy: long-term results with the low 99mTc-sestamibi protocol'. Nuclear medicine communications. 2006 Sep. ; 27(9): 709-13, doi: $10.1097 / 01 . m n m .0000230071 .54318 .28$, indexed in Pubmed: 16894325.

21. You CJ, Zapas JL. Diminished dose minimally invasive radioguided parathyroidectomy: a case for radioguidance. Am Surg. 2007; 73(7): 669-72; discussion 673, indexed in Pubmed: 17674938.

22. Assadi M, Yarani M, Zakavi SR, et al. Sentinel node mapping in papillary thyroid carcinoma using combined radiotracer and blue dye methods. Endokrynol Pol. 2014; 65(4): 281-286, doi: 10.5603/EP.2014.0038, indexed in Pubmed: 25185850.

23. Dabbagh Kakhki VR, Aliakbarian $\mathrm{H}$, Fattahi A, et al. Effect of radiotracer injection volume on the success of sentinel node biopsy in early-stage breast cancer patients. Nucl Med Commun. 2013; 34(7): 660-663, doi: 10.1097/MNM.0b013e3283619d07 indexed in Pubmed: 23604225.

24. Tibblin S, Bizard JP, Bondeson AG, et al. Primary hyperparathyroidism due to solitary adenoma. A comparative multicentre study of early and long-term results of different surgical regimens. Eur J Surg. 1991; 157(9): 511-515, indexed in Pubmed: 1683573. 